\title{
Rational Jihad: Measuring Rationality of Jihad Resolution
}

\author{
Zakiya Darojat \\ Faculty of Adab and Humanities \\ Syarif Hidayatullah State Islamic University \\ Jakarta, Indonesia \\ zakiya.darojat@uinjkt.ac.id
}

\begin{abstract}
The World now is facing the common enemy namely terrorism, and Islam becomes one of world culprits as an actor of terror. The doctrine of jihad is accused as the cause of radicalism in Islam. Jihad is considered as an emotional expression which is implemented by terror actions, taking some Indonesian Islamic social movements as samples. This article seeks to show that the use jihad as the basis of their struggle is considered as a rational movement, and not solely caused by emotional expression. This article was $s$ written using socioscientific history approach which meant that historical approach combined with other social science approaches, such as sociological, theological-normative, and political approaches. The main sources of data were taken from literature related to the topic, documentation study, and in- depth interviews with relevant parties. This article considers that jihad was a rational act for the actors. They showed collective acts that were structured and organized through mobilization mechanism to bring them strategic resources for sustainable acts. The writer also viewed that some Islamic social movements, or in this case was the Jihad Resolution, was triggered not only by the costbenefit calculation but also by the pursuance of martyrdom as expected by every mujahidin, as well as a practice of altruism by the doers. This is what the writer considered as Religio-Rational Action Theory (RRAT).
\end{abstract}

Keywords-Jihad; Islamic social movement; Jihad Resolution; Radicalism; Rationality.

\section{INTRODUCTION}

Every November 10, the Indonesian Nation commemorates the Heroes Day as a day to commemorate Suroboyo's heroes' (arek-arek) struggle led by Bung Tomo against the allied troops that wished to regain their power in Indonesia. It was a very fierce battle by arek-arek Suroboyo, until then the allied forces called this battle with one sentence, "once and forever". Many people do not know that this battle is inspired by a holy call known as the Resolution of Jihad. Jihad becomes a holy call for every Muslim to defend their countries from the grip of colonization. Jihad also encourages Muslims to join a social movement

Meanwhile, the social movement theorists debate whether social actors base their actions on emotional feelings or rational arguments that take into account cost-

benefit calculation. This is what later in the sociological study of the movement gives birth to two different perspectives on the emergence of a movement. Michael Bonner in Jihad in
Islamic History; Doctrines and Practice argues that Islamic History understands the meaning of jihad by being associated with motivation, mobilization and political power. Jihad is not only an interreligious, civilizational and state conflicts, but also a clash between groups within Muslim societies[1]. While Wictorowicz in Resource Mobilization Theory and Rational Action Theory initiated by sociologists such as Quintan Wictorowicz in Islamic Activism; A Social Movement Theory Approach claims that movement as something rational[2]. The movement is not seen as an irrational explosion aimed at alleviating psychological tension, but rather as a structured statement organized through mobilization mechanisms that provides strategic resources for ongoing actions. Charles Kurzman in Social Movement Theory and Islamic Studies also states that the perpetrators of the movement are rational individuals [3]. In many cases they gain more pragmatic advantages rather than satisfaction of the ideology they believe in. Likewise, Charles Tilly, John McCarthy, and Mayer Zald in Identity, Grievances and New Social Movement suggest that mobilization requires both the resources and the rational orientations to action. Actors in movements are not under the shadow of the sentiments, emotions and ideologies that guide their actions, but must be understood in terms of logic, cost, and profit as well as opportunities for action [4].

In contrast, the collective behaviour theory proposed by some sociologists such as Ralph Turner and Lewis Killian, in Theory of Collective Behaviour who view that the actors of the social movement are not fully aware of the outside forces that govern their lives.[5]. They are seen as emotional individuals who are reacting to situations that are beyond their control. They seek only martyrdom and the result of social rift and experience of misery, oppression, and suffering that occur both at the individual level and at the group level.

By using the parameter of elements in a social movement, i.e. collective identity, motivation, mobilization and resonance framing, this article tried to measure how far the rationality of the Jihad and resonance framing, this article tried to measure how far the rationality of the Jihad Resolution declared by some NU scholars in Surabaya is. Social movement theorists see important relationships between collective identity with mobilization and activism. In the view of Melucci, collective identity can develop long before mobilization[6]. It produces solidarity and mutual moral investment in series of issues. 
Similarly, as is believed by Carry Rofesky Wickham, that the same interests and ideas ultimately motivate the emergence of collective action. That means that individuals often join a group or movement to express committed commitments, values and beliefs, sometimes more often they are motivated by more than self-interest and a desire for profit. From here onwards the movement's leaders are able to mobilize these individuals into politics by announcing a holy call for struggle or other normative reasons for collective action. This is what the social movement theorists name as the framing of motivation [7].

\section{METHOD}

This article was written by using socio-scientific history approach which meant historical approach combined with other social science approaches, such as sociological, theological- normative, and political approaches. Sociological approach is used to show how is the role of the actor or the leader of social movement, what kind of mobilization they used, and so on. Theological-normative approach is used to know that the understanding of 'nash' (for this case is text about 'jihad') of the holy Quran can give someone influence to do something. The main sources of data were taken from literature related to the topic, documentation study, and indepth interviews with relevant parties.

\section{RESULTS AND DISCUSSIONS}

\section{A. Motivation of Jihad Resolution: Strengthening the Moral Leaders of the Nation}

After the proclamation of the Indonesia's independence on August 17, 1945 and Japan was defeated from the allied forces, the Dutch still had a desire to re-instill its power in Indonesia. In September 15, 1945, by riding a British soldier (the alliance) who would disarm and repatriate the Japanese army, the NICA (the Netherlands Indies Civil Administration) landed in Jakarta. Some cities in Java such as Semarang and Bandung had been handed over to the Alliance (UK). In October 25, 1945, England also landed in Surabaya. Faced with the return of invaders to Indonesia, the newly independent Republic of Indonesia seemed nervous and refrained from fighting. The government is looking forward to a diplomatic solution and tended to leave it alone when the Dutch flag was again flown in Jakarta.

Faced with this precarious situation, some NU leaders and ulamas took the initiative to respond and took political stance in order to defend the sovereignty of the state. KH. Hasyim Asy'ari summoned Kyai Wahab Hasbullah, Kyai Bisri Syamsuri and several other kyais (the Islamic clerics) to gather the kyais all over Java and Madura. In the presence of Kyai Abbas Buntet, Kyai Satori Arjawinangun, and Kyai Amin Babagan Ciwaringin, in 21 and 22 October 1945, at the Office of Ansor Nahdlatul Oelama (ANO) PB in J1. Bubutan VI / 2, Surabaya, they held a deliberation to determine the attitude on the condition of the country. The evening of 22 October 1945, the great chairman (Rois Akbar) NU, KH Hasyim Asy'ari conveyed a mandate containing the principles of the rules on the obligations of Muslims both men and women in jihad defending the homeland. PBNU meeting was led by the Great Chairman KH Ahmad Wahab Hasbullah then read a declaration and a call for jihád fí sabilillah to strongly insist the Government of the Republic of Indonesia to declare holy war against the alliance. This call was popularly called as the Resolution of Jihad [8].

Since the issuance of the Jihad Resolution of October 22, 1945, all East Java residents, especially Surabaya, were on standby waiting for the British landings whose news had been circulating since the second week of October 1945. Bung Tomo's speeches through Radio Pemberontakan that ignited the spirit of the people with the cries of "Allahu Akbar" burnt the spirit of the struggle of the East Java residents from Governor, Mayor, until the villagers. This jihad call triggered the Mass War for three days, 27, 28, and 29 October 1945. Arek-arek Surabaya with the spirit of jihad attacked the 49th Brigade Mahratta led by Brigadier General Aulbertin Walter Sothern Mallaby. More than 2,000 British troops were killed in the three-day attack. Brigadier AWS Mallaby himself was killed on 31 October 1945 due to a grenade throw in an incident at Hotel International. This three-day battle triggered British anger that led to the outbreak of the battle of 10 November 1945. By the British, the November 10th heroic event that lasted for three weeks was remembered as the most gripping war and commemorated with a brief phrase "Once and Forever".

The Resolution of Jihad and the NU's determination to fight against the far superior alliance resulted in the NU figures to be different from the previous attitude and tradition that were moderate, cooperative and accommodative toward Dutch and Japanese colonials. According to Greg Fealy, NU's attitude was in harmony with his understanding of Islamic law [9]. As Sunni believers, NU believed that the previous Dutch and Japanese governments, although not Muslims, must be obeyed because of their legitimate military power, administering orderly government, and not arbitrarily interfering in religious affairs. But when the proclamation was declared, the legitimate government was the government of Indonesia, so according to NU, their duty was to support it, whatever the stakes were.

\section{B. Patterns of The Jihad Resolution Mobilization: Santri Militarization}

The period of the physical revolution since the Japanese occupation in 1942 to 1945 was the year in which the spirit to seize independence was utterly fervent in the hearts of the Indonesian youths. Japan exploited this spirit to form troops (laskar) that would be used as preparation to face the Greater East Asia War. In October 3, 1943 Saiko Sikikian from the Japanese Occupation Army issued Osama Seirei No. 44 on the establishment of PETA (Pembela Tanah Air) or Bo- ei Giyugun Kanbu Renseitai consisting of 65 Daidan (battalions) in Java and 3 battalions in Bali. Each Daidan was commandeered by one Daidancho. Of the 65 battalions, the 20 commanders and their chief of staff were kyais. Because of the large number of kyais who became Daidan 
commanders, the January 24, 1944 Asia Raya newspaper questioned the Daidancho's name as to whether it would be given an additional "Daidancho kyai".

A year later, in December 19, 1944, Masyumi decided to form a military named Hezbollah in Jakarta. In particular, its members were Muslim youths in Java and Madura. Furthermore, under the banner of Masyumi, Islamic mass organizations had mobilized themselves by forming Laskar Hizbulah in their respective regions. Throughout October 1945 Hezbollah continued to consolidate and recruit members in various regions such as in Central Java, East Java, West Java, Yogyakarta, Jakarta, and even Sumatra. In Central Java, Hizbullah Kedu Division, which was received full support from KH Saifuddin Zuhri, a Masyumi Party politician, led by Saleh Ansyari. In the Residency of Pekalongan, Divisi Hizbullah, named Sharif Hidayatullah Division, led by commander Djohar Arifin which was later replaced by $\mathrm{H}$. Abu Bakrin. In Yogyakarta, Hezbollah Division named Sultan Agung Division or Mataram Division led by KH Badawi side by side with the regular army of TKR Division IX led by Mayjend Sudarsono. In Yogyakarta, the majority of Hezbollah members were ulama and Muhammadiyah citizens.

The recruitment of Hezbollah members within NU bodies was done through the consuls of NU and pesantren. The first exercise of the Laskar Hizbullah took place in Cibarusa, Bogor, from February to May 1945, followed by 500 Muslim youths. Among them were the young kyai from various pesantren, such as KH Mustofa Kamil (Banten), Kyai Mawardi (Solo), Kyai Zarkasyi (Ponorogo), Kyai Mursyid (Pacitan), Kyai Syahid (Kediri), Kyai Abdul Halim (Majalengka) Kyai Thamir Dasuki (Surakarta), Kyai Roji'un (Jakarta), Kyai Munasir Ali (Mojokerto), Kyai Abdullah and Kyai Wahib Wahab (Jombang), Kyai Hasyim Latif (Jombang), Kyai Zainuddin (Besuki), Kyai Sulthan Fajar (Jember ), etc. They were trained by kyai officers of PETA and from Dai Nippon such as Captain Yanagawa.

Armed with modern military knowledge from PETA and Hezbullah, these Muslim kyai and youth in each region then formed paramilitary units. the members were the students and residents around the boarding school. These were later to be called Sabilillah Troops. The Sabilillah army was officially established as a result of the Congress of Masyumi I or known as Congress on November 7, 1945. If Hezbullah was designated as a purely military entity and was often referred to as soldiers from santri, then Sabilillah was a military unit of the citizens in guerrilla warfare against enemies and often referred to as laskar kyai. Sabilillah was based in Malang tasked to mobilize and invite the pesantren and Muslims who were not accommodated in the unity of Hizbullah because of the age or other factors [10].

The people who lived in Surabaya, Gresik, Lamongan, Tuban, Bojonegoro, Mojokerto, Jombang, Pasuruan, Malang and other eastern areas, who culturally had same roots of the tradition as NU were communities during which the Japanese occupation had been trained militarily; Keibodan and Seinendan. Those involved in Keibodan were estimated to number about one million people, while those involved in Seinendan numbered about five million people. Keibodan (watch corps) was a police auxiliary organization for fire and air strike, consisting of young people aged from 25 to 35 years. While seinendan (Youth Corps) was a semi- military organization for young people aged from14 to 22 years, formed in April 1943 [11].

Based on these considerations and facts, the Resolution of Jihad is aroused by ulamas. With a mature calculation, those Muslims had been transformed into a force that could be considered to struggle against the invaders, the call of jihâd fi sabilillâh which was used as the basis for the struggle and spirit of the people began to be disseminated through the sermons in mosques, mushalls, and so forth. Since then, the kyai and their santri (students of traditional Islamic boarding house [pesantren]) began to flow from the pesantren in Java and Madura to Surabaya. The pesantren and branch offices of $\mathrm{NU}$ and their bransches soon became the headquarters of Hezbullah and Sabilillah to bring together santri who wanted to fight. With a fervor and shriek of Allahu Akbar, Bung Tomo (1929-1981) incited the people's spirit to fight for independence until the last drop of their blood. The dawn of November 10,1945, was a great battle between the people of Indonesia and the British army. In this heroic battle, thousands of Indonesians died. Despite the loss of many fighters, this November 10th battle became a symbol of sacrifice and zeal for unity for the sake of revolution.

\section{Framing the Jihad Resolution: Jihad in Expelling Colonial Invaders from the Earth of Indonesia}

As elaborated earlier, during the Dutch colonial era, NU applied more moderate, accommodative, cooperative and even apolitical stance. Once again, the moderate attitude (tawassut) and choosing the way of peace was based on the Sunni political thought adhered by NU. One of NU's top officers, Idham Cholid, in a cadre training course in 1969 illustrated how flexibility was necessary in maintaining selfexistence. The story of Imam Syafi'i and Imam Hambali in the court of mihnah in the time of the Caliph Al-Ma'mun (w.833) exhibited how the attitude of the graceful Imam Syafi'i made him safe from prison so that he could continue his preaching in society. While Imam Hambali, who chose to be strictly opposed to the principle of the ruler, did make him a martyr [9].

NU followers' attitude in this political activity was reflected in the attitude of Rais' Am NU, Wahab Hasbullah who stated that the participatory attitude and the attitude of choosing the NU peace road had its limits. What if a government was prominently violating the Shari'a or preventing Muslims from carrying out their religious obligations, then the resistance was justified. The change in NU's political stance took place during the Japanese occupation and subsequent periods. The radical change of NU's politics came about because NU was faced by a situation that wanted NU to participate in the effort to save the Indonesian nation and state. The attitude of the Japanese government that forced Muslims to do seikere cannot be 
ignored just because it violated Islamic aqidah and shari'a. Likewise, although in the NU Congress of 1936 in Banjarmasin NU declared Indonesia as Negoro Islam or Dar al-Islam (Islamic State) even under the Dutch colonialism, when the Indonesian government was established, it became a collective obligation to expel invaders from Indonesia.

\section{CONCLUSION}

The important milestone of NU's political role in defending the state's sovereignty reflected in the Jihad Resolution describes that NU is not only as a religious organization that makes the theological foundation ideology of its movement but also as a social movement that had logical calculations in mobilizing its citizens with the spirit of jihad to struggle defending the country. The mobilizers of the Jihad Resolution which later became an inspiration in the heroic battles of 10 November 1945 were the pesantren kyais known for their unique traditions. The tradition of pesantren which emphasizes the five basic tenets of sincerity, simplicity, ukhuwah Islamiyah (Islamic brotherhood), self-help, and the spirit of the struggle are the basic capital for santri in their participation in fighting for religion and state. In addition, the strong emotional ties between the kyai and his santris made the process of mobilization and recruitment work very easily. The relationship of patronage and absolute obedience between kyai and santri in pesantren are not only motivated and based on the understanding that kyais are their caregivers, or as heirs of the Prophets, but also more based on the capacity and scientific capabilities attached to the kyai.[11] In other words, the person who is not knowledgeable may have no charisma and wisdom, so there is no obedience to him. Charisma, dignity and obedience to kyai are the factors to make thousands of students united to fight to expel invaders from the earth of Indonesia.

\section{REFERENCES}

[1] Michael Bonner, Jihad in Islamic History. New Jersey: Princetton University, 2008.

[2] Quintan Wictorowicz, Islamic Activism; A Social Movement Theory Approach. Indiana: University Press, 2004.

[3] Charles Kurzman, Social Movement Theory and Islamic Studis. Indiana: University Press, 2004.

[4] C. Tilly, J. M. Carthy, dan M. Zald, Identity, Grievances and New Social Movement. Philadelphia: Temple University, 1984.

[5] R. Turner dan L. Killian, Collective Behaviour. New York: Free Press, 1987.

[6] D. Singerman, The Networked World, dalam Islamic Activism. Indiana: Indiana: University Press, 2004.

[7] C. R. Wickham, Interest, Ideas, and Islamist Outreach in Egypt dalam Islamic Activism. Indiana: University Press, 2004.

[8] G. El-Guyanie, Resolusi Jihad Paling Syar'i. Yogyakarta: LKiS, 2010.

[9] G. Fealy, Ijtihad Politik Ulama. Yogyakarta: LKiS, 2003.

[10] Z. M. Bizawie, Laskar Ulama-Santri \& Resolusi Jihad. Jakarta: Pustaka Kompas, 2014.

[11] K. Y. Soon, Antara Tradisi dan Konflik; Kepolitikan Nahdlatul Ulama. Jakarta: UI Press. 